\title{
Ecological neo-Narodnism and the peasant economy: history and contemporary relevance
}

\author{
Marco P. Vianna Franco ${ }^{1}$ \\ Universidade Federal de Minas Gerais, Brazil \\ Konrad Lorenz Institute for Evolution and Cognition Research, Austria
}

\begin{abstract}
Based on the ecological utopianism of Narodnik thinkers, this article assesses the programmatic concept of ecological neo-narodnism, as put forth by Martinez-Alier (1987), addressing (1) to what extent it conforms to the intellectual legacy of the Narodniki? (2) what are its main theoretical foundations and policy recommendations for a peasant economy in the $21^{\text {st }}$ century? and (3) how it contributes to contemporary social and environmental challenges. It explores in detail the ecological economic theories which can be applied to the peasant economy according to the ideology of ecological neo-narodnism, the latter analyzed from the perspectives of the fields of political economy and political ecology. Peasant movements are addressed as the manifestation of such a worldview. Finally, the contributions of ecological neo-narodnism to overcome current social and environmental challenges are discussed and associated with economic degrowth.
\end{abstract}

Keywords: Narodnism; ecological neo-narodnism; peasant movements; rural communes

\section{Résumé}

Sur la base de l'utopisme écologique des penseurs Narodnik, cet article analyse le concept programmatique de néo-narodnisme écologique, tel que présenté par Martinez-Alier (1987), en examinant (1) dans quelle mesure il se conforme à l'héritage intellectuel des Narodniki; (2) quels sont ses principaux fondements théoriques et recommandations politiques pour une économie paysanne au XXIe siècle; et (3) comment cela contribue aux défis sociaux et environnementaux contemporains. Il explore en détail les théories économiques écologiques qui peuvent être appliquées à l'économie paysanne selon l'idéologie du néo-narodnisme écologique, en analysant cette dernière du point de vue des domaines de l'économie politique et de l'écologie politique. Les mouvements paysans sont considérés comme la manifestation d'une telle vision du monde. Enfin, les contributions du néo-narodnisme écologique aux défis sociaux et environnementaux actuels sont discutées et associées à des appels à la décroissance économique.

Mots-clés: Narodnisme; néo-narodnisme écologique; mouvements paysans; communes rurales

\section{Resumen}

Basado en el utopismo ecológico de los pensadores Narodnistas, este artículo analiza el concepto programático del neo-narodnismo ecológico, presentado por Martinez-Alier (1987), y incluye (1) en qué medida se ajusta al legado intelectual de los narodniki; (2) cuáles son sus principales fundamentos teóricos y recomendaciones de política para una economía campesina en el siglo XXI; y (3) cómo contribuye a los desafíos sociales y ambientales contemporáneos. Explora en detalle las teorías económicas ecológicas que pueden aplicarse a la economía campesina conforme la ideología del neo-narodnismo ecológico, este último analizado desde las perspectivas de los campos de la economía política y la ecología política. Los movimientos campesinos son

\footnotetext{
${ }^{1}$ Dr. Marco P. Vianna Franco, postdoctoral fellow, the Konrad Lorenz Institute for Evolution and Cognition Research, Austria. Email: mpvianna "at" gmail.com. PhD in Economics from the Center for Development and Regional Planning (Centro de Desenvolvimento e Planejamento Regional), of the Federal University of Minas Gerais, Brazil. The author would like to thank Hugo da Gama Cerqueira and João Antonio de Paula for their support, Antoine Missemer for the French translation of the abstract, and three anonymous reviewers and the editor for their constructive comments on earlier versions of this article. The usual disclaimers apply.
} 
presentados como la manifestación de tal cosmovisión. Finalmente, las contribuciones del neo-narodnismo ecológico para superar los desafíos sociales y ambientales actuales son discutidas y asociadas al decrecimiento económico.

Palabras clave: Narodnismo; neo-narodnismo ecológico; movimientos campesinos; comunas rurales

\section{Introduction}

The revolutionary socialist movements that existed in Russia in the $19^{\text {th }}$ century, especially from the 1860s, are often loosely referred to as a single political and intellectual group of opposition to the Tsarist regime called the Russian populists, or Narodniki. ${ }^{2}$ The emancipation of the serfs in 1861 and other reforms promoted by Tsar Alexander II marked the downfall of feudalism in Russia, being replaced by a new system that, according to the Narodniki, encouraged the exploitation of peasants by landlords and threatened the existence of the traditional system of rural communes (the obshchina). The communes were composed of small and sparsely distributed communities whose mode of production was collectively decided by local councils; in the eyes of Russian revolutionary figures, these institutions reflected the true essence and will of Russian peasants. ${ }^{3}$ The proposed type of agrarian reform maintained the most fertile lands in the hands of the nobility and excluded any sort of indemnification, consequently hindering any significant improvement in the life of the mass of poor peasants (Walicki, 1979).

The importance given to the traditional obshchina by the Narodniki had environmental implications, since communes did experience environmental degradation under certain conditions. Josephson et al. (2013, pp. 38-49) discuss the relations between peasant agriculture and environmental change in late imperial Russia, contending that "the peasant commune had perhaps the greatest human influence on the environment before the industrial revolution and the rise of the city in Russia." The complex social changes in peasants' attitudes towards agricultural science and the impacts of the communal system on land productivity were key elements in the analyses of Narodnik thinkers. The authors also claim that "peasants accumulated considerable knowledge over time, and that their techniques became damaging only under pressure of population increase or when they tried to introduce them in different environments."

The "conquering of the steppe" since the time of Ivan the Terrible in the $16^{\text {th }}$ century sought to control and populate a vast expanse of land at the frontiers of the Russian empire (especially the Ukrainian plains and the Caucasus) which meant farming the grasslands. It meant a profound change from earlier days in which peasants would live in the forest heartland, seeking subsistence from cereal and animal farming. By the late $19^{\text {th }}$ century, although peasants often made use of the then-available agricultural technology, they were still perceived by Tsarist policymakers as backward and feeble-minded, and there were pressures to produce more food for a rapidly growing urban population and for export markets. The communal system fared badly under market rules: it led peasant households to exhaust the soil, once they had only a temporary claim over it; and it induced the formation of smaller plots of land, inefficiently scattered around the village, which prevented the production of surpluses for trade and sale. On the other hand, peasants could share the risk of crop failure. The commune also assured a more diverse assortment of crops, made fertilizers available, and tried to coordinate soil use against depletion by means of the three-field system, in which one third of the soil always lays fallow for recovery.

Josephson et al. (2013) affirm that the reforms of Tsar Alexander II, despite conceding the emancipation of the serfs demanded by the revolutionary intelligentsia, did not achieve their goal of improving agricultural output, because the social structures of rural areas barely changed, with serfs becoming tenants and more fertile

\footnotetext{
2 The term populism comes here as a free translation from the Russian word referring to the ideology of narodnichestvo, stemming from "narod" - people or folk. The term "narodnism" is widely used with the same specific meaning and is here given preference, given the multiple uses of the word "populism."

${ }^{3}$ The names of Aleksandr Herzen (1812-1870), Nikolai Chernyshevsky (1828-1889), and Nikolay Mikhailovsky (18421904) stand out among a long list of prominent Narodnik intellectuals working in Russia or abroad. According to Vianna Franco (2020, p. 2), "[n]arodnism was in fact composed of several different ideological currents along the second half of the $19^{\text {th }}$ century, including anarchists, nihilists, and social revolutionaries." In the $20^{\text {th }}$ century, Narodnik ideas served as inspiration for the Bolsheviks (Frank, 1990) and Russian environmental thought in general (Weiner, 1988).
} 
lands remaining in the hands of the nobility. While liberals hoped that Western large-scale agricultural practices would be implemented in Russia, peasants were in general skeptical of the benefits of the market, remaining unconvinced by foreign views of success based on the creation of surplus and profit-making:

The outsiders wanted to increase the productivity of the soil to support the projects of the state. But the peasants were not in the least concerned with these issues, but with family, subsistence, and communal support (Josephson et al., 2013, p. 43).

Narodnik thinkers acknowledged and praised such peasant values and attitudes. They believed in "people's rustic, tellurian qualities (...) and rejected as false the whole modern idea of the liberation of humanity through the domination of nature driven by markets and science" (Keane, 2016). The centrality of the peasant question in narodnism was well summarized by Berlin (1994 [1978], p. 235), according to whom the unicity of purpose of narodnism was given by its utopian views on the peasantry as a class:

What were the ends of populism? Violent disputes took place about means and methods, about timing, but not about ultimate purposes. Anarchism, equality, a full life for all, these were universally accepted. It is as if the entire movement - the motley variety of revolutionary types which Franco Venturi describes in his book [Venturi, 1960] so well and so lovingly - Jacobins and moderates, terrorists and educators, Lavrovists and Bakuninists, 'troglodytes', 'recalcitrants', 'country folk', members of [revolutionary movement] 'Land and Liberty' and of 'The People's Will', were all dominated by a single myth: that once the monster was slain, the sleeping princess - the Russian peasantry - would awaken without further ado and live happily for ever after.

Therefore, and as will be explained in detail below, Narodnik economic thought can be characterized as a form of socialism which is simultaneously scientific and utopian (Vianna Franco, 2020). If conjugated with the rejection of the Promethean view of the eternal abundance of natural resources and the call for wealth distribution as a sound moral imperative and social policy, the Narodnik ideology can be regarded as a type of ecological utopianism within the frame of ecological economic thought presented by Franco (2018). MartinezAlier (1987) characterizes ecological utopians as left-wing social energeticists who do not support the idea of human domination over nature, arguing in favor of more egalitarian forms of social organization while living within given biophysical boundaries. The emphasis on the role of the obshchina is the cornerstone of such a claim, figuring as an element of the real world which is subject to social policy and serves as a constitutive basis for an ecologically and economically viable social organization. In this sense, contemporary intellectual currents such as ecosocialism and eco-Marxism also draw key insights from this late $19^{\text {th }}$-century ecological utopianism (Vianna Franco, 2020).

Having as a starting point the ecological utopianism of Narodnik thought, this article brings the discussion to more contemporary debates. When Martinez-Alier (1987) calls for an ecological neo-narodnism, what is entailed in this worldview? To what extent does it conform to the ecological utopianism of the Narodnik? What are its main theoretical foundations and policy recommendations for a peasant economy in the $21^{\text {st }}$ century? How does it contribute to contemporary social and environmental challenges?

Section 2 presents the concept and contents of ecological neo-narodnism. Section 3 explores in detail ecological economic theories which can be applied to the peasant economy according to the ideology of ecological neo-narodnism. The assessment of such an ideology is divided into the perspectives of the fields of political economy and political ecology. Existing peasant movements are addressed in Section 4 as the manifestation of such a worldview. Section 5 discusses the contributions of ecological neo-narodnism to current social and environmental challenges, and Section 6 offers some final remarks. 


\section{The intellectual legacy of the Narodniki in the $2^{\text {th }}$ century}

Throughout the $20^{\text {th }}$ century, the intellectual legacy of the Narodniki spread to other parts of the world, inspiring socialist peasant movements, especially in the global South, in their resistance against the rapid development and consolidation of the capitalist mode of production of agricultural commodities based on largescale farming and fossil fuels, which endures to this day (Bernstein, 1977; Tepicht, 1975). By the 1960s, in addition to rural flight and its pernicious social consequences, caused by the process of commodification of the peasant economy, there was a growing awareness of environmental damage on a planetary scale. Modern industrial agriculture is one of the main culprits of problems such as massive biodiversity loss, desertification, soil and water contamination, ocean acidification, chemical pollution, and climate change (Rockström et al., 2009). The acknowledgement of such a "metabolic rift" (Foster, 2000) between nature and the economy, and particularly between ecosystems and modern agriculture (Wittman, 2009), prompted a renewed interest in the so-called peasant or agrarian question.

One of these initiatives brought Narodnik thought back to the peasant agenda. Martinez-Alier (1987) conceptualized ecological neo-narodnism - the terms 'ecopopulism', 'ecological agrarianism', or 'environmentalism of the poor' are used interchangeably - as an alternative ideology capable of reversing the social and environmental maladies occasioned by industrial agriculture. His inspiration was the ecological utopian current of the ecological economic thought that thrived between the 1880s and the 1930s (Franco, 2018), combining the precepts of scientific rationality with anti-Promethean and egalitarian views.

(...) [U]niversal egalitarian ecological utopianism is one "appropriate ideology" for the poor people of the world (against both the ideologies of "waiting for economic growth while preserving inequality" and "to each country, its adaptive, appropriate technology"). Though it is an ideology which could be called "ecological neo-narodism", it can find much support in the tradition of rational-empiricist study of human ecology (Martinez-Alier, 1987, p. 18).

These rational-empiricist studies of human ecology were able to assess scarcity in terms of energy and materials. Meanwhile, utopian thought is useful to unveil, in more specific terms, the purposes of humankind. If the resources available to us and our objectives are clearly identified, it should then be possible to determine how to distribute such resources, intra- and intergenerationally, so that all people can live happily within Earth's biophysical limits.

In particular, Martinez-Alier (1987) emphasized the need for a renaissance of narodnism in developing countries since the restitution of land in favor of landless peasants or smallholders would contribute to a more sustainable ecological balance between agricultural production and ecosystems, as well as alleviate social inequality and other negative effects of commodification processes in rural areas. The empirical findings of social energetics suggest that a wide substitution of industrial with peasant modes of agricultural production would not impede feeding growing populations, as the latter are more efficient than the former from an energetic perspective, given their relatively higher independence from fossil fuels as inputs to production (Pimentel, Hepperly, Hanson, Douds \& Seidel, 2005; Pimentel et al., 1973; Smith, Williams \& Pearce, 2015). ${ }^{4}$ Hunger is a social rather than an ecological problem, driven by migration restrictions, food waste, energy-intensive consumption patterns, and income inequality. Moreover, the exhaustible character of hydrocarbon-based agricultural production hints at a reinvigorated role of labor-intensive farming in the future (Veermer, 1976).

Ecological neo-narodnism is not to be regarded as a reaction to the post-modern discrediting of science and social progress, or as local resistance against capitalist expansion, but as the result of a rational analysis of the obvious contradictions between the precepts of human ecology and capitalism. Ecological neo-narodnism, therefore, aims to provide a universal ideological platform where different cultures can perpetuate economic

\footnotetext{
${ }^{4}$ Such a result contrasts with those based on a monetary perspective, in which agricultural productivity is higher on industrial farms, mostly due to underpriced inputs (e.g. oil and chemical products), which, in turn, do not have their costs internalized or are subjected to an imposed social discount of future demand (Martinez-Alier, 1987).
} 
reproduction through the adoption of socially and environmentally sustainable modes of social organization (Martinez-Alier and Schlüpmann, 1991, p. 316).

As a programmatic concept, ecological neo-narodnism links the empirical evidence arising from studies in social energetics to the construction of theories and formulation of public policies reflecting the need for a social organization based on communities as the unit of social life, and on an egalitarian distribution of natural resources. Such a concept adds to $19^{\text {th }}$-century narodnism a stronger sense in which economic activity must be considered as biophysical flows and stocks of energy and matter, a notion that might prevent the systemic destruction of natural processes which are indispensable for the maintenance of economic reproduction. Despite this very important addition to the ideas of Narodnik thinkers (which corresponds to the adjective "ecological" in the expression "ecological neo-narodnism"), narodnism itself does not seem to have become outdated over the last 150 years. Their ecological utopianism remains a viable present-day alternative to tackle worsening social and environmental problems.

Another novel feature of ecological neo-narodnism is that it transcends the question of land ownership. It deals with the distribution of every natural resource that is important to satisfy basic human needs. MartinezAlier (1987, p. 235) gives the example of oil, claiming that a part of its reserves should be destined for the peasant economy, so that the more arduous tasks in agricultural production are performed by machinery and not human labor. Today, confronted with imminent climate breakdown, the access to water and renewable energy or the right to live in a clean environment constitute better examples. Notwithstanding the issue of distribution of natural resources, low capital intensity and energy efficiency remain as key elements of such a peasant economy.

The limited character of natural resources is then more openly present in ecological neo-narodnism than in its intellectual sources. In the $19^{\text {th }}$ century, the scale of natural processes was far greater than that of economic processes, making it difficult or irrelevant to advocate for any clear limits to the growth of the human economy. Conversely, natural and economic processes currently present similar orders of magnitude, which is a result of over a hundred years of relentless economic growth, with unpredictable and potentially irreversible consequences for the habitability of the planet by humans. This distinction justifies an emphasis on redistribution rather than on growth of productive forces. Energy and material flows into social systems are to be rearranged, not increased; if anything, these flows might need to decrease if future generations are to have their basic needs fulfilled (Rockström et al., 2009). Before it is possible to show how ecological neo-narodnism can contribute to this discussion, the relevant ecological economic theories associated with it need to be assessed.

\section{Ecological economic theories and the peasant economy}

Ecological economic theories are those arising from assumptions regarding the dynamics of energy and material transformations in economic processes based on empirical evidence obtained from comprehensive research in social energetics. Such a biophysical approach to the social sciences, and to economic science in particular, entails the need to assess the human economy by means of energy and material flow accounting, i.e., the accounting of the flows and stocks of energy and matter which are relevant to concrete production, distribution, and consumption processes. Energy and material flow accounting offers empirical evidence supporting the development of economic theories and public policy recommendations. On the other hand, the different ways in which such biophysical transformations may sustain social provisioning and be appropriated by different social groups lead to a diverse range of ecological economic theories. Therefore, there is also a normative aspect to such theories, which involves moral choices related to resource distribution, social ideals, and policymaking (Franco, 2018).

To Martinez-Alier (1995, p. 146), the association between normative aspects of ecological economic theories and ecological neo-narodnism can be analyzed within at least two disciplinary fields of knowledge: political economy, understood as "the study of the economics of distributional conflicts", and political ecology, "the study of the ecology of distributional conflicts." The ideology of ecological neo-narodnism would merge the objects of these scientific fields at the ontological and epistemological levels, even though their emphases and rationales are not the same. Moreover, the implications of this merger for interdisciplinary research are 
wide in scope, pertaining to the broader environmental social sciences. ${ }^{5}$ When applied to the peasant question, Martinez-Alier translates these normative aspects as a "theoretical connection between smallholding [peasant agriculture] and ecology [which] must come through a theory of 'peasant resistance' and 'moral economy'." Class struggle is an element of vital importance to understand how peasants can resist exploitation or competition using the natural resources that are available to them, and maintaining their traditional social relations and moral principles. The universality of class struggle acts as a unifying element, and neo-narodnism is, in this sense, a term comparable, for example, to neo-Zapatism (Toledo, 1999).

The expressions "ecological agrarianism" and "environmentalism of the poor" more adequately convey this universality. Also, since the term "ecological neo-narodnism" calls for a historical knowledge that is not always readily available, Martinez-Alier would later choose to adopt "environmentalism of the poor" as the main catchphrase for the same set of ideas (Martinez-Alier, 2002). However, he did not drop altogether the use of term alluding to its Narodnik lineage, as will be the case here.

\section{Ecological neo-narodnism as political economy}

The political economy of ecological neo-narodnism focuses on the peasantry as an agent capable to avert the indiscriminate penetration of market systems and, hence, to lead the transition from capitalism to socialism (Martinez-Alier, 1989). Martinez-Alier's views on the peasant economy are based on the social energetics of Narodnik (and also Marxist) thinker Sergei Podolinsky (1850-1891) (Martinez-Alier \& Naredo, 1982) and the agricultural economics of the Russian organization-production school made famous by Alexander Chayanov (1888-1937). ${ }^{6}$ Podolinsky's attempt to conflate energetics and Marxism is one of the issues discussed by Martinez-Alier, who is, at first, skeptical:

...our conclusion is that Marxism would have to be much revised since there are epistemological obstacles (the use of categories from Political Economy, such as 'production', 'labour-value', 'capital') and ideological obstacles (the vision of a two-stage transition to communist abundance and equality) (Martinez-Alier \& Naredo, 1982, p. 207).

Martinez-Alier (1987, p. 1989) criticized how Marxism is closer to an economicist than to a materialistenergetic approach. In addition, he opposed the emphasis on economic growth - rather than on redistribution of Marxists and development economists. Conversely, more recent literature on eco-socialism and eco-Marxism would reconnect Marxism and ecological economics (Burkett, 2009; Foster, 2000; Löwy, 2015). Also, some interpretations of Marxism were, to Martinez-Alier, quite representative of ecological neo-narodnism, such as José Carlos Mariátegui's (1894-1930) combination of materialist and romanticist elements in his argument in favor of a collective organization of indigenous peasants for the success of socialism in Peru (Martinez-Alier, 1989).

Martinez-Alier (1997) focuses on Chayanov's views on the peasant economy as inspiration for his ecological neo-narodnism. Chayanov differed from liberals and orthodox Marxists in his "praise of peasant economic rationality, in the case of high population density, [which] contains arguments based as much in

\footnotetext{
${ }^{5}$ Environmental social science is here understood as human-environment interactions research (Moran, 2010). Vaccaro, Smith and Aswani (2010, p. 1) explain the concept as both "the realization that landscapes and the multitude of components they contain cannot be understood without serious consideration of past and present human communities" and "the recognition that human societies cannot be understood without analyzing their interactions with the environments that supported them."

${ }^{6}$ There were at least four different currents of Soviet agricultural economics in the 1920s. In addition to the school of Chayanov and his colleagues Nikolai Makarov and Aleksandr Chelintsev, the works of Nikolai Kondratiev stood out, and he studied agricultural markets and their impacts over farmers' decisions; also Marxist agrarianist Lev Kritsman on the role of class structure and wage labor in rural areas; and of right-wing agrarianist Lev Litoshenko, who opposed the organizationproduction school, arguing that, in a modern monetary economy, households composed by peasant farms would maximize the difference between earnings and expenditures, denying the labor-consumer balance suggested by Chayanov (Franco, 2020).
} 
economic efficiency as in equity" (p. 227). He argued that peasant households constitute a distinctive form of social organization, whose economic rationality does not abide by the principles of a capitalist enterprise. These ideas had been put forth by Narodnik economists such as Vasily Vorontsov (1847-1918) and Nikolai Danielson (1844-1918), who believed that, as a non-capitalist institution of high efficiency, the Russian commune had a bright future in socialist economies, and its existence and expansion should be ensured by a strong state. It was a viable alternative to the social problems of the then-growing industrial agriculture of Western economies. This opposition to industrial agriculture and its social and environmental implications would be the main thread connecting $19^{\text {th }}$-century narodnism and neo-narodnism - ecological or not - throughout the $20^{\text {th }}$ century.

Chayanov's economic theory was anchored to statistical evidence. It included correlations between sown area, family size, and household consumption demands, which would inform how production would take place in a determined household, based on the assumption that peasants behaved according to a balance between the toil of labor and satisfaction of consumer demands. Such a balance corresponded to a level of self-exploitation within the rural household, which varied from family to family, according to objective (e.g. composition, size, or ages of family members) and subjective (values, relationship to the land, traditions, or technical knowledge) factors. Furthermore, peasants could, occasionally, act contrarily to the precepts of neoclassical economics, failing, for instance, to seek profit maximization. This result might also apply to other social groups facing a choice between the drudgery of labor and the benefits of consumption (Sivakumar, 2001).

The demise of the peasant economy to the benefit of industrial agriculture would be the result of the imperative of productivity gains and of a low income-elasticity of demand for agricultural products, which meant that part of the rural population would inevitably lose their roles and be forced to move into urban areas (Martinez-Alier, 1997). However, Chayanov realized that peasants could more freely adapt to scenarios of high population densities, rearranging household labor in ways that capitalist social relations would not easily accomplish. In this sense, in a setting of growing population densities, peasants would intensify production. They would not be tied to wage-labor relations, having the flexibility to create new sorts of tenancy contracts (such as sharecropping) which encourage higher marginal productivity by linking personal efforts to earnings. However, these alleged advantages of the peasant economy would be accompanied by the above-mentioned notion of "self-exploitation" within rural households, an issue subject to fierce criticism by Marxists. In any case, Chayanov's labor-consumer balances and correlations between household and farm sizes led to a "convincing application of marginalist economics to non-capitalist institutions (family labor, and customary needs satisfied by self-provisioning and by the market)" (Martinez-Alier, 1997, p. 228).

Martinez-Alier (1997) acknowledged Nicholas Georgescu-Roegen as another important agrarian economist of Narodnik inclination. A scholar of Romanian descent, Georgescu-Roegen and his intellectual contemporaries (e.g. sociologist Dmitrie Gusti [1880-1955]) had already been acquainted with Narodnik agrarian economics since the 1930s, whereas Chayanov's work would only become known to most Western economists in the 1960s. In his essay Economic Theory and Agrarian Economics, Georgescu-Roegen (1960) had not yet formulated his biophysical approach to its full extent, but his pro-peasantry economic analysis and questioning of the rationality of market systems were visibly of Narodnik character. He called Chayanov "one of the most praiseworthy Russian agrarians" (p. 10), and restated the importance given by Chayanov to the development of a "theory of the economic behavior of the peasant" (p. 11). This essay would be the germ of his main theoretical works of the 1970s, which combined a utility theory which stressed the role of social institutions, Chayanovian agrarian economics, and social energetics.

Georgescu-Roegen's 1960 essay would face intense criticism, as had often happened to intellectual contributions focusing on peasants as important economic agents. Critics stated that neo-Narodnik economics naively portrayed the peasantry as an economically undifferentiated or homogeneous class, with an idealized view of the ability, stability, and efficiency of peasants in their competition against industrial agriculture. To these critics, peasant and industrial farms had different objectives: the former, subsistence; the latter, profits. Household labor and rural wage-labor implied completely different conditions of production, which were connected through markets. Furthermore, they claimed that industrial agriculture would not have thrived if it did not possess higher yields and surpluses per unit area. The arguments of the neo-Narodniki were, thus, 
fallacious (Patnaik, 1979). In his rejoinder to Patnaik, Georgescu-Roegen (1981) reaffirmed that his views were accurate in many historical settings, mentioning, for instance, Soviet data according to which peasant farms could produce more efficiently, both in quantity and quality, than the collective Soviet farms.

Paitnak's problem with the pro-peasantry economics of the neo-Narodniki was, in fact, not the evidence on their ability, stability, or efficiency, especially in societies with high population densities. In her reply to Georgescu-Roegen, she explained her criticism as follows:

Our concern was with the interpretation of this fact [higher efficiency of peasant farming in terms of yield per unit area] by the neo-Populists in a one-sided and apologetic manner, by taking the output value per unit area as the only index of 'efficiency', locating it within a theory which denies the existence of class differences and exploitative relations within the peasantry, and rationalising the objectively-existing distress of small peasants in terms of subjective models of 'peasant equilibrium' (Patnaik, 1981, p. 244).

Patnaik's main concern was the neglect of the consequences of "self-exploitation" within household labor in neo-Narodnik economics. High-yield peasant farms would often be led by starving and overworked families. In this sense, the exploitative wage-labor relations of capitalist economics were also present in privately-owned, small peasant farms. In socialist economies, the enduring presence of smallholders was a result of organizational and other institutional problems of the planned transition into collective industrial farms, and not the influence of their abilities and efficiency. To Patnaik (1981, p. 245), "it is only under socialist planning that the family farm can become viable and a transitional form to socialised production in agriculture [be obtained]."

Patnaik seems to dismiss the historical relevance of peasant farms or their role in the future of agriculture, as well as the institutional views held by Chayanov and Georgescu-Roegen. She acknowledges the legitimacy of the peasantry at best as a transitional form, although conceding that the organization of rural communes increases the real income of rural households: "the private plot provides the extra bit of variety in diet and extra income for small luxuries" (Patnaik, 1981, p. 245). Her reproach toward the abstraction level of neo-Narodnik economics and their alleged negligence of social differentiation and class struggle is, however, partly justified. Pro-peasantry economic theories of Chayanovian character, i.e., marginalist theories in non-capitalistic settings, entail the application of equilibrium models to the peasant economy. ${ }^{7}$ In this sense, they can be as misguided as the bulk of neoclassical economic theories (Arnsperger \& Varoufakis, 2006; Daly, 2007; Ruiz-Villaverde, 2019). The idealization of the peasant household farm as the unitary economic agent can be interpreted as an attempt to forge a way to apply the neoclassical approach to the peasant question. On the other hand, the institutional and organizational aspects of Chayanov's economics, as well as his support for the creation of peasant cooperatives, cannot be ignored. To Sivakumar (2001), Chayanov's macroeconomics was proof that depicting him as a marginalist was more a rhetorical argument than an assessment based on theory:

As regards his macro-level preoccupations, nothing could be less marginalist than Chayanov's model. Consider, for example, the theoretically eclectic collection of concepts that influence the resource allocation process in Chayanov's analysis: stochastic or chance factors, surplus-value of merchant capitalists, linkage between product and input markets, co-operativized decision making, state regulation of markets, plus demographic considerations and the dynamics of landman ratios (Sivakumar, 2001, p. 40).

The term "neo-populism" used by Patnaik (Georgescu-Roegen preferred "agrarianism"; here, "neonarodnism" is used) relates to Chayanovian economics. It has a very different meaning than the term "narodnism", as presented above. Both relentlessly supported the peasant economy, cooperatives, and asked

\footnotetext{
${ }^{7}$ Marginalism is adopted here in a wide sense, corresponding to theories in which efficient economic activity is linked to the equilibrium between revenues and costs at the margin.
} 
similar questions, e.g. how internally differentiated or egalitarian the obshchina was. But otherwise, they adopted different assumptions, theories, and methodologies. Patnaik (1981, p. 246) asserted that "neoclassical ideas are nothing if not anticlassical", but she did not suggest, nor should she, that Chayanovian neo-populism was, in fact, anti-Narodnist. Nevertheless, one must acknowledge that the ideas of the Narodniki of the $19^{\text {th }}$ century have less in common with neo-populist economists of the $20^{\text {th }}$ century than one might suppose.

Ecological neo-narodnism, as proposed here, would ideally be closer to a renewal of original Narodnik ideas, namely their ecological utopianism, to which is added the modern biophysical approach of ecological economic thought. The Narodniki assessed the peasant economy using the obshchina as unit of analysis, and not the rural household. Communal ownership, production, and consumption were the economic categories on which their political economy was based, and cooperation was a fundamental element to understand the economic behavior of peasants.

Martinez-Alier (1997) sided with Georgescu-Roegen against Patnaik, which is understandable, given the ideological split between socialists who supported the smallholders and those in favor of the large-scale collectivization of agriculture. Moreover, by the 1970s, environmental issues could not be overlooked, and Patnaik did not bother to analyze the comparative advantages, in ecological terms, of peasant farms over industrial ones. But these arguments do not mean that ecological neo-narodnism, as an ideology that fosters the development of an ecologically sound peasant economy in the $21^{\text {st }}$ century, should be viewed as the narrow application of a sustainable Chayanovian economics. It should be the embodiment of Narodnik ecological utopianism, coupled with a strong biophysical approach to the economy, as professed by modern ecological economists.

The growing importance of environmental challenges at planetary level is the novel element that calls for a "greening" of the debate on the peasant economy and reinvigorates arguments in favor of ecological neonarodnism. Human ecology is crucial to the understanding of peasant agriculture, whose mode of organization of production relies less on markets and their energy-intensive inputs, and more on cheap and energetically efficient agroecological techniques. Such an organization would favor the maintenance of the services provided by the soil, watersheds, biodiversity, and other types of natural endowment, while allowing for the maintenance of the conditions of production of the farm without the need for greater amounts of monetary capital.

Moreover, farm sizes and the rationality of peasants (and the ensuing agricultural practices and techniques) toward their environment are not necessarily in agreement with ecological precepts. Ecologically sound behavior depends on the level of peasants' involvement with the market, as prices do not reflect biophysical reality, and on their capacity to secure their own livelihoods, as extreme poverty might lead to abuse of the services provided by nature (Martinez-Alier, 1995).

There are important economic implications stemming from the fact that peasant agriculture is more energy-efficient than industrial agriculture. Given the exhaustible nature of fossil fuels and the associated negative externalities of their use, it would be reasonable to assume a scenario of increasing energy prices in the long run. Does it mean that peasant farms running on a solar energy budget are bound to gain competitiveness in this new scenario? Martinez-Alier (1995, p. 144) contends that the disconnection between prices and environmental costs of economic production casts doubt upon this assumption. "The prices of the economy are embedded in the social perception and valuation of externalities and opportunity costs for future generations"; they can often go in an opposite direction from biophysical indicators. However, with the introduction of "ecologically-corrected prices", by means of a political process, agroecological peasant farms could become the cornerstone of a sustainable food production system for a densely populated planet. Without such a correction to the current economic system, the adaptation skills of peasants praised by Chayanov would be limited, as well as the positive impact of their environment-friendly energetics.

While such "ecologically-corrected prices" might not be enough to promote deeper changes in the mode of social organization in rural areas, peasants are not going to disappear without them. Martinez-Alier (1995) gives the following reasons: household labor is versatile and cheap; energy prices will likely have some positive effect on the competitiveness of peasant farms; population densities tend to grow each year; and social awareness toward the broken relationship between humans and nature is escalating. 
Martinez-Alier's political economy of ecological neo-narodnism is, in brief, an ecologically adjusted approach to Chayanovian economics, much in the same way as proposed earlier by Georgescu-Roegen. A stronger utopian element and the consequent call for a more radical overhaul of the current economic rationality would bring it closer to the ideology put forth by $19^{\text {th }}$-century Narodnik thinkers. Communality and cooperation are key concepts, not only as part of a true Narodnik intellectual heritage, but also as adequate frameworks to interpret economic behavior toward common problems - in this case, planetary-level environmental peril. A paradigmatic shift is needed, a new worldview pushing for social change, based on the notions of communality and cooperation at the local, regional, and global levels. Such a shift would entail a vision of the peasant economy not in terms of the aggregate behavior of independent smallholders or households, but of structured communities with emergent properties pertaining to their collective rationality and organization.

\section{Ecological neo-narodnism as political ecology}

As "the study of the ecology of distributional conflicts" (Martinez-Alier 1995, p. 146), political ecology analyzes different forms of appropriation and use of natural resources and sinks for the purposes of social provisioning. A field that first gained ground in the late 1970s, especially through the initiatives of geographers and anthropologists, it focuses on power inequality as a factor conditioning the access to such resources and sinks and the distribution of the benefits and burdens associated with them. Power is, therefore, a key concept to understand how humans interact with nature and with each other (Svarstad, Benjaminsen \& Overå, 2018). Ecological analyses based on the natural sciences, such as assessments of energy and material flows between environmental and social systems, would not be enough to understand the dynamics of cultural development. Hence, political ecologists reject energetic reductionist views and strive to understand emerging social phenomena in their own terms, before analyzing them jointly with knowledge from the natural sciences. Moral issues, normative debates, and social ideals are, in this sense, as important as social energetics or ecosystem studies:

The determinants of ecological distribution are in some respects natural (climate, topography, rainfall patterns, minerals, soil quality and so on). They are clearly, in other respects, social, cultural, economic, political and technological (Martinez-Alier, 2002, p. 73).

Only a small fraction of the use of natural resources is tied to the satisfaction of basic human needs. Accordingly, the destination of most natural resources appropriated by humans cannot be explained by physiological aspects of human ecology in the same way that it is by those of plant or animal ecology. Social, cultural, economic, political, and technological issues may lead to radically different institutional settings, in which the use of natural resources is either sustainable or not, and their distribution more egalitarian or not (Martinez-Alier, 1988).

The concept of environmental justice is at the core of political ecology. It analyzes the connections between power inequality and environmental degradation, as well as the social conflicts arising from ecologically unequal distributions or exchanges. However, it is more commonly referred to as a movement within environmentalism, a third current that challenges both the advocates of radical preservationism and those in favor of a utilitarian conservationism based on efficiency gains (Martinez-Alier, 2002, p. vii). Its logic lies with the environmental benefits of a more egalitarian distribution of resources aiming at the satisfaction of basic human needs, and contrasts with conservation policies based on national parks and other types of protected areas that segregate nature from humans. It also opposes theories in favor of ecological modernization as the solution to environmental problems, as professed by top-down approaches to the notion of sustainable development which, in many cases, go against the interests of poor and indigenous populations (Leff, 2004). ${ }^{8}$

\footnotetext{
${ }^{8}$ Advocates of ecological modernization argue that environmental challenges might be successfully overcome through a "green" reform of the current economic system (Mol, 2002). Unwavering economic development would be the best option for escaping ecological crises while fostering employment, given the power of technological innovations to reduce resource use and waste generation (Andersen \& Massa, 2000; Fisher \& Freudenburg, 2001). It "hypothesizes that while the most challenging environmental problems of this century and the next have (or will have) been caused by modernization and
} 
This third current entails a strong cultural dimension to the environmentalist movement, summoning communities to take charge of the management of natural resources while respecting their cultural identities. It envisions the conception of new modes of production, distribution, and consumption based on a renewed ethical platform that reproduces the cultural heritage of such communities, thereby organically fashioning a new environmental rationality (Leff, 2004; Toledo, 1990).

The environmental justice movement is composed of many grass-roots organizations that question the weight of political and economic power in decision-making processes involving the appropriation and use of natural resources and sinks. Such organizations stand up against a myriad of abuses over land, air, and water. They are formed by, and act in favor of vulnerable populations (typically the poor or indigenous communities), standing up against exhaustion of natural resources and reckless disposal of waste and pollutants by private corporations (Martinez-Alier, 2012).

With respect to the peasant economy, the environmental justice movement tackles land ownership and use as a pivotal matter for securing the livelihood of smallholders and agroecological communities. Also, peasants have a history of coevolution with their environment, constituting more sustainable and adaptable modes of social organization. Their traditional agricultural techniques have created a variety of new crops while protecting biodiversity and maintaining water and chemical cycles. Thus, social and ecological arguments are joint, "implying a link between peasant resistance movements and the ecological critique of both agricultural modernization and 'scientific' forestry"' (Martinez-Alier, 2002, p. 13).

Ecological neo-narodnism is an ideology for the environmental justice movement. The foundation in ecological science, the awareness of the limited character of natural bounty, and the egalitarian social ideal are features that thrust Narodnik thought into the $21^{\text {st }}$ century, restoring the obshchina as an institution capable of addressing contemporary challenges of the social and ecological order. This movement brings with itself the Narodnik utopia of a social system based on communal values and cooperation, which would also be embedded in the rationality and behavior of the agroecological peasantry of today.

While Martinez-Alier (2011, p. 146) sees ecological neo-narodnism as "in essence a pro-peasant movement that uses arguments from ecological economics and other sustainability sciences", the political language of power relations is emphasized. ${ }^{9}$ The solution to environmental and social problems would not be plainly technical or economical, but rather political, through the struggle of grass-roots movements such as those seeking environmental justice (Leff, 1986; Martinez-Alier, 1989).

Strong, rational arguments can be brought against both so-called economic rationality and ecological managerialism. Meanwhile, at present, there is a big struggle, fought with unequal means and unequal opportunities, to set the environmental-economic agenda in the world, especially to determine which are the important issues. This fight is not yet about which decisions to take; it is rather about inclusions and exclusions of topics to be discussed. Who should set the environmental-economic agenda? (...) [A]ll attempt to direct the ecological debate in particular directions, and they have unequal access to the media and unequal power and money (MartinezAlier, 1988, p. 118).

\section{Peasant movements}

Pro-peasant social movements representing the tenets of environmental justice gained ground in the 1960s, alongside other initiatives of left-wing ecologism, such as the pacifist communalism of the American counterculture movement, or the anarchist communalism professed by social ecologist Murray Bookchin

industrialization, their solutions must necessary [sic] lie in more - rather than less - modernization and 'superindustrialization"' (Buttel, 2000, p. 61). Therefore, a sustainable future could be achieved by means of new business opportunities in response to a higher demand for ecologically competitive products. Such a cornucopian view rests on controversial claims about the biophysical decoupling of the economy, focusing on relative efficiency gains, disregarding absolute levels of material and energy use by humans, and making the case for further unlimited and unequal appropriation of resources.

${ }^{9}$ For a detailed theoretical discussion on power relations in political ecology, see Svarstad, Benjaminsen and Overå (2018). 
(1921-2006). The oil crises of the 1970s added momentum to these undertakings (more concrete examples of such movements are provided below), as well as the growing awareness within academic circles of mounting environmental havoc caused by the prevailing economic rationality, among which Club of Rome's Limits to Growth (Meadows, Meadows, Randers \& Behrens, 1972), Rachel Carson's Silent Spring (Carson, 1964), and other landmark works of economists with an interest in the biophysical approach to economics, such as Boulding (1966), Daly (1968), and Georgescu-Roegen (1971). Although the first actions were seen in Europe and America, by the 1980s environmental justice movements had spread across the global South, mainly in India, parts of Africa and Latin America, in association with the issue of unequal ecological exchanges between North and South (Hornborg \& Martinez-Alier, 2016; Martinez-Alier, 1987).

The formation of globally integrated production chains and underlying international power relations revealed how the basically unidirectional flow of commodity exports from South to North led to a relentless expansion of industrial agriculture and its carbon-based high monetary yields. Such an imbalance in transfers of energy and matter was combined with deteriorated terms of trade, leaving poor countries indebted and in social turmoil (Altvater, 1992). This transnational economic dynamics would lead to an overly simplistic view, in which environmental harm was caused by wealth in the North and poverty in the South. This conclusion would easily and misguidedly be appropriated by discourses trying to ecologically justify the need for economic growth and more "green" business opportunities. The response in the South would come in the form of social movements of all sorts, among them peasants calling for environmental justice.

In India, environmentalist movements have been addressing the issue of social justice at least since the 1970s, criticizing the existence of differential access to natural resources, development-induced displacement, and gender inequality. Rajan (2014) traces the intellectual origins of such movements to Indira Gandhi's stance in favor of a compromise between the environment, economic development, and justice, to be achieved by focusing on the improvement of the lives and livelihoods of the vulnerable masses. However, her emphasis on the role of appropriate technologies and association between poverty and environmental damage were not quite aligned with the concept of environmental justice set forth here. For instance, the Chipko movement of the 1970s, in which rural women from Northern India would hug trees to prevent them from being cut down, was fiercely opposed to Western models of technological development and social change. Their struggle can be more clearly related to Gandhian economic philosophy and particularly to the "economy of permanence" of Kumarappa (1945), which centered economic analysis on small, democratic communities and how to make them self-sufficient in terms of basic human needs, through subsistence agriculture and craftsmanship. Unlike the industrial development of Western societies, the economy of permanence would reflect nature's perennial capacity to sustain life. It takes into consideration environmental vulnerabilities, human creativity, spiritual values, and altruistic behavior (Corazza \& Victus, 2015). ${ }^{10}$

In Latin America, environmental justice movements grew in the 1990s, reclaiming the rights of indigenous groups or rural workers over arable land, an effort which endures to this day (Altieri \& Toledo, 2011). In Mexico, Zapatists fought for autonomous and democratic management of the natural resources of their territories (Brass, 2005; Stahler-Sholk, 2007; Toledo, 1999; Van Der Haar, 2005; Washbrook, 2005). In Brazil, the Rural Landless Workers' Movement called for land reform in favor of smallholders. In Andean countries, peasants reminisce about a biologically diverse and ecologically sound pre-Hispanic agriculture while organizing themselves around what Martinez-Alier (1987, p. 244) calls "retrospective utopianism." In a more institutionalized setting, the Buen Vivir movement in Ecuador is at once a social movement and political philosophy characterized by different views and values regarding concepts such as human development and welfare, which focus on community life and harmonious human-nature relationships. ${ }^{11}$ According to the worldview of Buen Vivir, nature would not only present intrinsic value, but bear rights of its own.

\footnotetext{
${ }^{10} \mathrm{On}$ an interesting side note on the relations between narodnism and Marxism in India, the term "Narodnik" has been up until recently used in a demeaning way to identify, among other things, "opponents of West Bengal's industrialization under the CPIM [Communist Party of India (Marxist)] government" (Kerswell, 2018, p. 420). For more details on the tensions between Marxism and Narodnism, see Tvardovskaia (1978) and Vianna Franco (2020).

${ }^{11}$ Buen Vivir is the Spanish expression adapted from the Quechuan Sumak Kawsay, meaning "to live in plenitude", a notion inspired by old Andean and Amazonian traditions.
} 
Environmental disruption arising from the creation of artificial needs, for instance, would breach the rights of Pachamama ("Mother Earth" or "Mother Nature") (Zaffaroni, 2011). Economic activity should support and be supported by elements such as solidarity, local autonomy, regenerative use of resources and the right of all peoples and communities to a self-appraised, dignified existence. Furthermore, Buen Vivir advocates propose that social and economic regulations should be performed at the community level, reducing market and state power over individual and collective choices. Acosta (2015) acknowledges the need to confront power relations which are strongly unfavorable to those represented by Buen Vivir. The challenge to transform reality goes way beyond discourse implementation, even though some steps have already been taken in this direction, as illustrated by the incorporation of Buen Vivir as a constitutional principle in Ecuador. ${ }^{12}$

The above-mentioned examples of environmental justice movements conform to a culturalist approach to the peasant question. As affirmed by Brass (2002), agrarian movements all over the world have changed profoundly in the last two decades of the $20^{\text {th }}$ century, shifting focus toward "postmodern populist objectives." Peasant movements became less concerned with seizing control of state power or reforming social and economic systems, and more interested in revealing their identities, values, and traditions, which are usually ecologically sustainable and at odds with the logic of markets. Petras and Veltmeyer (2001), however, move beyond Brass's culturalist approach and portray contemporary peasant movements in a more powerful light. The authors acknowledge the significance of ethnicity and identity; however, they go beyond this to affirm that Latin American peasant movements are an actual force of change. They place the postmodernist approach into context and argue that such movements actually constitute a platform for criticism of neoliberal dominance, addressing fundamental class issues, shedding light on the capabilities of social systems based on cooperative behavior, and showing a deep understanding of power relations at all levels.

The question of ethnicity and positionality, translated as the search for identity and values in old traditions, is an important factor, but it does not suffice to grasp their raison d'être. Peasant movements seek systemic change, not mere survival of the old ways. They are equipped to confront capitalist institutions with up-to-date data and knowledge. Their egalitarian or socialist discourses are accompanied by propositions and alternatives related to resource management, economic development, human rights, freedom, and justice, always within the context of systemic change. ${ }^{13}$ In the face of global environmental catastrophe, the ecological argument might be a game-changing reinforcement to the discourses and alternatives put forth by the peasant movements of the $21^{\text {st }}$ century.

The internationalization process of such movements hint toward their goals of systemic change, as opposed to mere survival. The International Peasant's Movement La Via Campesina attests to this outward look. ${ }^{14}$ It claims to be an autonomous, pluralist, and non-partisan international initiative bringing together local and regional peasant movements in defense of food sovereignty as means to safeguard social justice and environmental health. Martinez-Alier (2011) sees La Via Campesina as the embodiment of ecological neonarodnism, not least due to the emphasis given in their discourse to the energetic efficiency of peasant agriculture and, hence, its ability, in general, to provide for humankind while minimizing environmental impacts. This is a fine example of the political application of ecological economic principles, which appears as a social demand and acts as feedback from activism to the development of ecological economic science.

\section{Contributions to current social and environmental challenges}

Theory and practice inspired by ecological neo-narodnism constitute an alternative to overcome the social and environmental challenges of the $21^{\text {st }}$ century, i.e., tackling inequality and complying with planetary

\footnotetext{
${ }^{12}$ Having its economy based on commodity exports, Ecuador still struggles to remain on a path toward the consolidation of the principles and practices of Buen Vivir, overcoming the power of influential groups linked to large-scale extractive projects, which typically lead to social and environmental losses (Villalba-Eguiluz \& Etxano, 2017).

${ }^{13}$ Bebbington (2000) provides an alternate view and calls for a more nuanced interpretation of rural development, focusing on human agency and "room to maneuver" within constraining institutions and structures.

${ }^{14}$ La Via Campesina was founded in 1993. It now comprises 182 local and national organizations in 81 countries from Africa, Asia, Europe, and the Americas, representing approximately 200 million farmers (https://viacampesina.org/en/, accessed on January $28^{\text {th }}$ 2019).
} 
boundaries that impose limits on human activity. ${ }^{15}$ The proposed systemic change is based on principles of communality and cooperation, as well as on the harmonious coevolution of humans and nature, preserving the balance between natural and economic processes and the survival of humankind itself. It refers to a paradigmatic shift, in which social justice dictates that minimum living standards should be granted for all, while ecological thresholds enforce a ceiling to the scale of economic processes vis-à-vis those of natural processes.

Therefore, ecological neo-narodnism is also about developed countries restraining their own activity levels, releasing scarce resources for more vulnerable territories to have their most basic needs satisfied. In this sense, there is a conflict between social and ecological targets. The former proposes a lower and the latter an upper limit to the scale of a given economy. These would correspond respectively to a social foundation and an ecological ceiling, as per Raworth's (2017) concept of "doughnut economics." Public policies should aim for the interval between these two boundaries, as meeting demands for social justice is essential to ensure public support for environmental issues; in turn, the observance of ecological thresholds would prevent large-scale social degradation as a result from halting ecosystem services. Food and energy security represent, in this sense, key aspects of "socially inclusionary and environmentally sound development strategies" (Sachs, 2015, p. 13). The current global imbalances in food (Patel, 2012) and energy (Arto, Capellán-Pérez, Lago, Bueno \& Bermejo, 2016) consumption demonstrate how far humankind still is from becoming a sustainable society, and how a systemic change might indeed be the solution.

The metabolic rift between economic and natural processes is particularly evident in industrial agriculture. The historical relations between society and nature have been dramatically altered by agricultural practices. Carbon-based industrial agriculture led to a metabolic rupture between the flows of energy and materials in natural and social systems, not to mention rural flight and qualitative environmental degradation. Peasant movements will be imbued with the task of overcoming the contradictions of current socioecological conditions in rural areas, rekindling agrarian identity and redeeming agroecological traditions which conform to biophysical limits, while providing humans with their most basic needs (Wittman, 2009). The case of climate change is quite illustrative:

In fact, industrial agriculture is one of the main drivers of climate change [see Robertson, Paul and Harwood (2000); Tilman, Cassman, Matson, Naylor and Polasky (2002)], carrying food around the world and imposing monocultures and mechanization and the use of agrochemicals while destroying biodiversity and its ability to capture carbon and "transforming agriculture from a producer of energy into an energy consumer." The solutions that Via Campesina puts forward are small scale agriculture, which is labour intensive, uses little fossil fuel energy and can actually help stop the effects of climate change; a genuine agrarian reform to strengthen peasant agriculture; promoting food production as the primary land use; and considering food as a basic human right that should not be treated mainly as a commodity. Local food production should be supported because it avoids unnecessary transport, while patterns of production and consumption that promote waste and unnecessary consumption by a minority of humanity should be stopped because hundreds of millions of people still suffer hunger (Martinez-Alier, 2011, p. 157).

The demands of environmental justice movements, therefore, entail a way out of the metabolic rift induced by industrial agriculture, which can be translated into the need for economic degrowth (Martinez-Alier, 2012). According to Kallis et al. (2015, p. 3), degrowth "calls for the decolonization of public debate from the idiom of economism and for the abolishment of economic growth as a social objective." More specifically, it points to "a desired direction, one in which societies will use fewer natural resources and will organize and live differently than today. 'Sharing', 'simplicity', 'conviviality', 'care' and the 'commons' are primary significations of what this society might look like." Degrowth, thus, constitutes a theoretical framework, idea, project, or

\footnotetext{
${ }^{15}$ According to Rockström et al. (2009), planetary boundaries are climate change, ocean acidification, stratospheric ozone depletion, nitrogen and phosphorus cycles, global freshwater use, change in land use, biodiversity loss, atmospheric aerosol loading, and chemical pollution.
} 
movement embedded in diverse fields of knowledge, such as political ecology, ecological economics, and moral philosophy, to which the ideology of ecological neo-narodnism is closely connected.

In this context, agroecological production systems are vital to the attainment of a prosperous and fair degrowth. Although the belief that diminished economic activity might lead to higher subjective wellbeing levels is controversial, with complex interactions taking place as the economy shrinks, some degrowth theorists argue that, even if not necessarily making individuals happier, the observance of proper policies could assure the fulfillment of basic human needs for all, and therefore a sustainable existence (Koch, Buch-Hansen \& Fritz, 2017). Still, fewer formal working hours, a stronger connectedness to other human beings and to the surrounding environment, widespread social equality leading to less envy, rivalry, or isolation, and increasing personal free time and autonomy are some of the elements that might link degrowth to enhanced life satisfaction levels (Sekulova, 2015). These elements are strikingly in line with the precepts of ecological neo-narodnism.

\section{Final remarks}

Ecological neo-narodnism was assessed as a viable alternative to deal with the social and ecological challenges of the $21^{\text {st }}$ century. It was argued that, if assessed from the standpoint of the field of political economy, it should move beyond Chayanovian economics to redeem the principles of communality and cooperation seen among the Narodniki of the $19^{\text {th }}$ century. Conversely, if assessed according to the tenets of political ecology, the concept of ecological neo-narodnism is a true intellectual heir of Narodnik thought. It is best represented by environmental justice movements; it combines the ethnic and local character of peasant movements with the need for their internationalization; it addresses power relations as a key issue for enforcing the rights of the peasantry; and it adds a new argument in favor of systemic change, namely economic degrowth.

The historical and contemporary issues discussed here are embedded in, and seek to inspire, the debate about the future of humankind on Earth, from the question of whether industrial capitalism is compatible with a sustained human existence on a finite planet (and, if not, what it should transition into and which elements are to be retained or discarded) to whether alternative socioeconomic systems, such as those in line with the ideology of ecological neo-narodnism, are, in fact, viable in the long-term. Utopias are needed in this debate, especially those which abide by our understanding of the reality of nature, its possibilities, and its boundaries.

\section{References}

Acosta, A. (2015). El Buen Vivir como alternativa al desarrollo: Algunas reflexiones económicas y no tan $\begin{array}{lllll}\text { económicas. } & \text { Política } & y & \text { Sociedad, } & \text { 52(2), }\end{array}$ http://dx.doi.org/10.5209/rev_POSO.2015.v52.n2.45203

Altieri, M.A., \& Toledo, V.M. (2011). The agroecological revolution in Latin America: Rescuing nature, ensuring food sovereignty and empowering peasants. The Journal of Peasant Studies, 38(3), 587-612. doi:10.1080/03066150.2011.582947

Altvater, E. (1992). Der Preis des Wohlstands: oder Umweltplünderung und neue Welt(un)ordnung. Westfalisches Dampfboot.

Andersen, M.S., \& Massa, I. (2000). Ecological modernization — origins, dilemmas and future directions. Journal of Environmental Policy \& Planning, 2(4), 337-345.

Arnsperger, C., \& Varoufakis, Y. (2006). What is neoclassical economics? Post-Autistic Economics Review, 38(1).

Arto, I., Capellán-Pérez, I., Lago, R., Bueno, G., \& Bermejo, R. (2016). The energy requirements of a developed world. Energy for Sustainable Development, 33, 1-13. http://doi.org/10.1016/j.esd.2016.04.001

Bebbington, A.J. (2000). Reencountering development: Livelihood transitions and place transformations in the Andes. Annals of the Association of American Geographers, 90(3), 495-520.

Berlin, I. (1994 [1978]). Russian thinkers. Penguin.

Bernstein, H. (1977). Notes on capital and peasantry. Review of African Political Economy, 4(10), 60-73. http://doi.org/10.1080/03056247708703339 
Boulding, K.E. (1966). The economics of the coming spaceship earth. In H. Jarrett (Ed.), Environmental quality in a growing economy (pp. 3-14). Johns Hopkins University Press.

Brass, T. (2002). Latin American peasants - new paradigms for old? The Journal of Peasant Studies, 29(3-4), 1-40. http://doi.org/0.1080/03066150412331311019c

Brass, T. (2005). Neoliberalism and the rise of (peasant) nations within the nation: Chiapas in comparative and theoretical perspective. The Journal of Peasant Studies, 32(3-4), 651-691.

Burkett, P. (2009). Marxism and ecological economics: Toward a red and green political economy. Haymarket Books.

Buttel, F.H. (2000). Ecological modernization as social theory. Geoforum, 31(1), 57-65. http://doi.org /10.1016/S0016-7185(99)00044-5

Carson, R. (1964). Silent Spring. Crest Book.

Corazza, C., \& Victus, S. (2015). Economy of permanence. In G. D'Alisa, F. Demaria \& G. Kallis (Eds.), Degrowth: A vocabulary for a new era (pp. 205-207). Routledge.

Daly, H.E. (1968). On economics as a life science. Journal of Political Economy, 76, 392-406. http://doi.org $/ 10.1086 / 259412$

Daly, H.E. (2007). How long can neoclassical economists ignore the contributions of Georgescu-Roegen? In H.E. Daly (Ed.), Ecological economics and sustainable development: Selected essays of Herman Daly (pp. 125-137). Edward Elgar.

Fisher, D.R., \& Freudenburg, W.R. (2001). Ecological modernization and its critics: Assessing the past and looking toward the future. Society \& Natural Resources, 14(8), 701-709. http://doi.org /10.1080/08941920119315

Foster, J.B. (2000). Marx's ecology: Materialism and nature. Monthly Review Press.

Franco, M.P.V. (2018). Searching for a scientific paradigm in ecological economics: The history of ecological economic thought, 1880s-1930s. Ecological Economics, 153, 195-203. http://doi.org /10.1016/j.ecolecon.2018.07.022

Franco, M.P.V. (2020). Conservation, economic planning and natural capital in early Soviet ecology. Ecosystem Services, 41, 101064. http://doi.org/10.1016/j.ecoser.2020.101064

Frank, J. (1990). Through the Russian prism: Essays on literature and culture. Princeton University Press.

Georgescu-Roegen, N. (1960). Economic theory and agrarian economics. Oxford Economic Papers, 12(1), 140. http://doi.org/10.1093/oxfordjournals.oep.a040831

Georgescu-Roegen, N. (1971). The entropy law and the economic process. Harvard University Press.

Georgescu-Roegen, N. (1981). On Neo-Populism and Marxism: A comment on Utsa Patnaik. The Journal of Peasant Studies, 8(2), 242-243. http://doi.org/10.1080/03066158108438135

Hornborg, A., \& Martinez-Alier, J. (2016). Ecologically unequal exchange and ecological debt. Journal of Political Ecology, 23, 328-333. https://doi.org/10.2458/v23i1.20220

Josephson, P., Dronin, N., Mnatsakanian, R., Cherp, A., Efremenko, D., \& Larin, V. (2013). An environmental history of Russia. Cambridge University Press.

Kallis, G., Demaria, F., \& D'Alisa, G. (2015). Introduction: Degrowth. In G. D'Alisa, F. Demaria \& G. Kallis (Eds.), Degrowth: A vocabulary for a new era (pp. 1-19). Routledge.

Keane, J. (2016). History of Russian populism provides important lessons for today. The Conversation, , October 23 ${ }^{\text {rd }}$. Retrieved from http://theconversation.com/history-of-russian-populism-providesimportant-lessons-for-today-67476

Kerswell, T. (2018). Studies of the Indian communist movement. Labor and Society, 21, 415-430. http://doi.org/10.1111/lands.12355

Koch, M., Buch-Hansen, H., \& Fritz, M. (2017). Shifting priorities in degrowth research: An argument for the centrality of human needs. Ecological Economics, 138, 74-81. http://doi.org/10.1016/j.ecolecon.2017.03.035 
Kumarappa, J.C. (1945). Economy of permanence. Sarva Seva Sangh Prakashan.

Leff, E. (1986). Ecología y capital: Hacia una perspectiva ambiental del desarollo. Universidad Nacional Autónoma de México.

Leff, E. (2004). Racionalidad ambiental: La reapropiación social de la naturaleza. Siglo XXI.

Löwy, M. (2015). Ecosocialism: A radical alternative to capitalist catastrophe. Haymarket Books.

Martinez-Alier, J. (1987). Ecological economics: Energy, environment and society. Blackwell.

Martinez-Alier, J. (1988). Ecological economics and eco-socialism. Capitalism Nature Socialism, 1(2), 109122.

Martinez-Alier, J. (1989). Ecologismo marxista y neo-narodnismo ecologista. Mientras Tanto, 39, 145-152.

Martinez-Alier, J. (1995). In praise of smallholders. The Journal of Peasant Studies, 23(1), 140-148.

Martinez-Alier, J. (1997). Some issues in agrarian and ecological economics, in memory of Georgescu-Roegen. Ecological Economics, 22, 225-238. http://doi.org/10.1016/S0921-8009(97)00076-1

Martinez-Alier, J. (2002). The environmentalism of the poor: A study of ecological conflicts and valuation. Edward Elgar.

Martinez-Alier, J. (2011). The EROI of agriculture and its use by the Via Campesina. The Journal of Peasant Studies, 38(1), 145-160. http://doi.org/10.1080/03066150.2010.538582

Martinez-Alier, J. (2012). Environmental justice and economic degrowth: An alliance between two movements. Capitalism Nature Socialism, 23(1), 51-73. http://doi.org/10.1080/10455752.2011.648839

Martinez-Alier, J., \& Naredo, J.M. (1982). A Marxist precursor of energy economics: Podolinsky. The Journal of Peasant Studies, 9(2), 207-224.

Martinez-Alier, J., \& Schlüpmann, K. (1991). La ecología y la economía. Fondo de Cultura Económica.

Meadows, D.H., Meadows, D.L., Randers, J., \& Behrens, W.W.III. (1972). The limits to growth: A report for the Club of Rome's project on the predicament of mankind. Universe Books.

Mol, A.P.J. (2002). Ecological modernization and the global economy. Global Environmental Politics, 2(2), 92-115. http://doi.org/10.1162/15263800260047844

Moran, E.F. (2010). Environmental social science: Human-environment interactions and sustainability. WileyBlackwell.

Patel, R. (2012). Stuffed and starved: The hidden battle for the world food system ( $2^{\text {nd }}$ ed.). Melville House.

Patnaik, U. (1979). Neo-populism and Marxism: The Chayanovian view of the agrarian question and its fundamental fallacy. The Journal of Peasant Studies, 6(4), 375-420.

Patnaik, U. (1981). Reply to Nicholas Georgescu-Roegen. The Journal of Peasant Studies, 8(2), 244-246.

Petras, J., \& Veltmeyer, H. (2001). Are Latin American peasant movements still a force for change? Some new paradigms revisited. The Journal of Peasant Studies, 28(2), 83-118.

Pimentel, D., Hepperly, P., Hanson, J., Douds, D., Seidel, R. (2005). Environmental, energetic, and economic comparisons of organic and conventional farming systems. BioScience, 55(7), 573-582.

Pimentel, D., Hurd, L.E., Bellotti, A.C., Forster, M.J., Oka, I.N., Sholes, O.D., \& Whitman, R.J. (1973). Food production and the energy crisis. Science, 182, 443-449.

Rajan, S.R. (2014). A history of environmental justice in India. Environmental Justice, 7(5), 117-121. http://doi.org/10.1089/env.2014.7501

Raworth, K. (2017). Doughnut economics: Seven ways to think like a $21^{\text {st }}$ century economist. White River Chelsea Green.

Robertson, G.P., Paul, E.A., \& Harwood, R.R. (2000). Greenhouse gases in intensive agriculture: contributions of individual gases to the radiative forcing of the atmosphere. Science, 289(5486), 1922-1925. http://doi.org/10.1126/science.289.5486.1922

Rockström, J., Steffen, W., Noone, K., Persson, Å., Stuart Chapin, F.III, Lambin, E.F., ... Foley, J.A. (2009). A safe operating space for humanity. Nature, 461, 472-475. https://doi.org/10.1038/461472a 
Ruiz-Villaverde, A. (2019). Editor's Introduction: The growing failure of the neoclassical paradigm in economics. American Journal of Economics and Sociology, 78(1), 13-34. http://doi.org/10.1111/ajes.12265

Sachs, I. (2015). Entering the Anthropocene: The twofold challenge of climate change and poverty eradication. In F. Mancebo \& I. Sachs (Eds.), Transitions to sustainability (pp. 7-18). Springer.

Sekulova, F. (2015). Happiness. In G. D'Alisa, F. Demaria \& G. Kallis (Eds.), Degrowth: A vocabulary for a new era (pp. 113-116). Routledge.

Sivakumar. (2001). The unfinished Narodnik agenda: Chayanov, Marxism, and Marginalism revisited. The Journal of Peasant Studies, 29(1), 31-60.

Smith, L.G., Williams, A.G., \& Pearce, B.D. (2015). The energy efficiency of organic agriculture: A review. Renewable Agriculture and Food Systems, 30(3), 280-301. http://doi.org/10.1017/S1742170513000471

Stahler-Sholk, R. (2007). Resisting neoliberal homogenization: The Zapatista autonomy movement. Latin American Perspectives, 34(2), 48-63. http://doi.org/10.1177/0094582X06298747

Svarstad, H., Benjaminsen, T.A., Overå, R. (2018). Power theories in political ecology. Journal of Political Ecology, 25(1), 350-363. https://doi.org/10.2458/v25i1.23044

Tvardovskaia, V.A. (1978). El populismo ruso. Siglo XXI.

Tepicht, J. (1975). A project for research on the peasant revolution of our time. The Journal of Peasant Studies, 2(3), 257-269.

Tilman, D., Cassman, K.G., Matson, P.A., Naylor, R., \& Polasky, S. (2002). Agricultural sustainability and intensive production practices. Nature, 418, 671-677.

Toledo, V.M. (1990). The ecological rationality of peasant production. In M. Altieri \& S. Hecht (Eds.), Agroecology and small farmer development (pp. 51-58). CRC Press.

Toledo, V.M. (1999). El otro zapatismo. Luchas indígenas de inspiración ecológica en México. Ecología Política, 18, 11-22.

Vaccaro, I., Smith, E.A., \& Aswani, S. (2010). Environmental social sciences: Methods and research design. Cambridge University Press.

Van Der Haar, G. (2005). Land reform, the state, and the Zapatista uprising in Chiapas. The Journal of Peasant Studies, 32(3-4), 484-507.

Veermer, D.E. (1976). Food, farming and the future: The role of traditional agriculture in developing areas of the world. Social Science Quarterly, 57, 383-396.

Venturi, F. (1960). Roots of revolution: A history of the populist and socialist movements in $19^{\text {th }}$-century Russia. Alfred A. Knopf.

Vianna Franco, M.P. (2020). Ecological utopianism in Narodnik thought: Nikolay Chernyshevsky and the redemption of land. Capitalism Nature Socialism. http://doi.org/10.1080/10455752.2020.1837896

Villalba-Eguiluz, C.U., \& Etxano, I. (2017). Buen vivir vs development (II): the limits of (neo-) extractivism. Ecological Economics, 138, 1-11. http://doi.org/10.1016/j.ecolecon.2017.03.010

Walicki, A. (1979). A history of Russian thought: From the Enlightenment to Marxism. Stanford University Press.

Washbrook, S. (2005). The Chiapas uprising of 1994: Historical antecedents and political consequences. The Journal of Peasant Studies, 32(3-4), 417-449.

Weiner, D.R. (1988). Models of nature: Ecology, conservation and cultural revolution in Soviet Russia. University of Pittsburgh Press.

Wittman, H. (2009). Reworking the metabolic rift: La Vía Campesina, agrarian citizenship, and food sovereignty. The Journal of Peasant Studies, 36(4), 805-826. http://doi.org/10.1080/03066150903353991

Zaffaroni, E.R. (2011). La Pachamama y el humano. In A. Acosta \& E. Martínez (Eds.), La naturaleza con derechos: De la filosofía a la política (pp. 25-137). Abya-Yala. 